\title{
ACQUIRING OF THE CULTURAL HERITAGE OF THE PEOPLES OF TURKESTAN BY THE RUSSIAN EMPIRE
}

\author{
Nodira Ibragimovna Alimova \\ $\mathrm{PhD}$ in History, \\ Assistant-Professor at the department "National idea, \\ Bases of morality and legal education" of Andizhan State University, \\ Andizhan region, \\ Republic of Uzbekistan
}

Article DOI: https://doi.org/10.36713/epra4316

\begin{abstract}
The article covers the occupation of Turkestan by the government of the Russian Empire and the looting of rare manuscripts and archival documents of the Uzbek people. In addition, it has been scientifically shown that many Oriental manuscripts, archives of the Khiva and Kokand khanates were confiscated from the libraries of princes' palaces, madrasahs and mosques in Turkestan and taken to Russian scientific centers.
\end{abstract}

KEY WORDS: Turkestan, manuscripts, archival documents, libraries, scientific centers, the imperial library.

\section{INTRODUCTION}

The history has shown that the state and society achieve social development primarily through the effective use of their cultural heritage. The Uzbek people, with its rich cultural heritage and great spiritual values, has made a great contribution to the development of human civilization, and this place has played the role of spreading advanced culture to the world. At a time when the land of Turkestan was trampled under the feet of invaders and under colonial oppression, the national culture of a people with such a great heritage was restricted, insulted, and its cultural monuments were looted. While the invaders sought to destroy the national and spiritual values of the Uzbek people by declaring them reactionary, they took away their material values, including valuable artifacts, rare monuments and works of art.

\section{METHODS}

Thanks to independence, the rich cultural heritage of the Uzbek people, which was insulted by the communist ideology during the Soviet era, is being restored. The spiritual recovery of the people is the social basis of economic reform. It is impossible to mobilize the people to strengthen independence without spiritual renewal. Therefore, the government of independent Uzbekistan pays great attention to the development of the spiritual sphere.

Manuscripts and other cultural relics preserved by the people for centuries were looted by Russian soldiers, Tsarist government officials, and specially sent orientalists during the occupation of Turkestan by Tsarist Russia. The commanders of the Russian military were ordered to seize historical and cultural monuments, works of art, manuscripts and documents, as well as his material wealth (treasures, ornaments, valuables of khans and beys) during the conquest of cities, principalities and khanates. Along with the conquest of the cities of Turkestan, many cultural treasures were confiscated from khans and beys, mosques and madrasahs.

\section{RESULTS AND DISCUSSIONS}

On behalf of the government, Turkestan Governor-General K.P. Kaufman himself was engaged. A special position has been introduced in the Governor-General of Turkestan to deal with this issue, and this responsible position has been assigned to the Adviser to the Governor-General of Turkestan, A.L.Kun. It was loaded for the day. He served as from 1867 to 1876 . in the presence of Kaufman he worked as a collector, a collector and registrar of cultural monuments, including Oriental manuscripts. A.L. Kun. In addition to fulfilling 
these duties as an orientalist, L.Kun also served as the Inspector General of Public Education in Turkestan.

In 1865 he graduated from the Faculty of Oriental Languages of the University of St. Petersburg. At the request of the Governor-General of Turkestan. The day was sent to work in Turkestan in 1867 [1.p.91]. His task was to search for the cultural riches of the country and send them to libraries, museums and scientific societies in central Russia. After the defeat of the Bukhara Emirate in the battles with the Russian invaders, the Emir of Bukhara Muzaffar was forced to make peace with Russia. According to the truce, part of the territory of the Bukhara Emirate was transferred to Russia, and the Zarafshan district was formed there, headed by Major General Abramov. From that time on, this general began to plunder the cultural riches of Samarkand and other regions.

At the time of the conquest of Samarkand, the Khoja Ahror Mosque was carefully preserved by its sheikhs as the manuscript of the holy book of the world's Muslims, the Qur'an who found out about this unique manuscript with the help of spies. Abramov, through Lieutenant Colonel Serov, the head of the Samarkand district, pressured the mosque staff to seize Mushaf and, by order of von Kaufmann, hand him over to the office of the Governor-General of Turkestan. The manuscript was then sent by Kaufman to St. Petersburg as a gift to the Imperial Library [2.p.92].

It is known that the Emir of Bukhara Muzaffarkhan was defeated in a decisive battle with the Russian army in Zirabulak and was forced to make peace on June 23, 1868, and the Emirate of Bukhara became a vassal of Russia. The people and state of Bukhara lost its independence, separated from the upper reaches of the Samarkand, Kattakurgan and Zarafshan rivers, and had to pay 500,000 gold [3.p.92]. Dissatisfied with Amir Muzaffarkhan's policy of surrender, the patriotic forces rallied around their leaders, Shahrisabz Begi Jurabek, Kitab Begi Bobobek, Kenesari Kasimov's son Sultan Sodiq, and Muzaffar's son Amirzoda Abdumalik Tora. Amir Muzaffar asked the Russians for help. General A. Abramov suppressed the uprising in Samarkand, and on August 11, 1870, he began to attack Shahrisabz and Kitab with the punitive troops. After a three-day battle, the cities of Shakhrisabz and Kitab were captured. Material and cultural treasures in the palaces of Jurabek and Bobobek were looted by the Russian military [4.p.93]. The head of Zarafshan district, Major General A. Abramov informed the GovernorGeneral of Turkestan that on September 3, 1870, after the conquest of the Book Duchy, a library of Oriental manuscripts was seized from the Jurabek Palace and brought to Samarkand. Kun reported reviewing the books. Upon hearing this news, the Governor-General of Turkestan, von Kaufmann, instructed Abramov to send the manuscripts to Tashkent, to the Governor-General's Office, in order to send them to St. Petersburg and the Imperial People's Library [5.p.93].

General A. Abramov General K.P. Kaufman's followed order. Along with the manuscripts he requested from the Jurabek Palace, A.LKun. By day, he sent more than 100 manuscripts to Tashkent, including the manuscripts collected in Shakhrisabz [6.p.93]. Orientalist A.L.Kun the day before the military march to Kitab and Shakhrisabz by the Governor-General of Turkestan, General A. Abramov was instructed to study and describe the cultural monuments in the occupied territories, to assist General Abramov in this matter, to inform the Governor-General of Turkestan and to send him monuments to take valuable museum exhibits, manuscripts and documents to Russia.

On October 9, 1870, A.L. Kun wrote a report to the Governor-General of Turkestan about the scientific materials he had collected during the Iskanderkul and Shakhrisabz expeditions. In this document, he spoke about his work on the collection of Oriental manuscripts in the principality of Shakhrisabz, including: "Also, various documents and about 300 books were seized. 26 of them were the most valuable and noteworthy. These books are for you to send to the Imperial People's Library at the request of His Highness. It was added to 76 books received by A.Abramov from Jurabek Palace "[7.p.94].

On October 9, 1870, Kaufman issued a resolution calling for the books to be sent to the Imperial People's Library, and on his instructions, A.L. Kun manuscripts, selected from books seized by the Abramovs, were sent to the Imperial People's Library in St. Petersburg. A list of some of the collected manuscripts has been preserved in the archives and sent to St. Petersburg: "Devo'ni ghazaliyoti Umarkhan", "Tarix-i Mir Said Sharif-i Roqim" and other invaluable manuscripts [8.p.94].

In early 1872, in Tashkent, tsarist officials found out that there was one of the oldest manuscripts of Firdavsi's "Shohnoma" decorated with miniatures, and gave it to the owner for a pittance. Given the uniqueness of this manuscript, Kaufman hastened to send it to the Imperial People's Library in St. Petersburg, and along with his letter of March 31, 1872, the Shahnameh was sent to the director of the Imperial People's Library.

After the government of Tsarist Russia subjugated the main part of the Kokand Khanate and the Emirate of Bukhara, it began to prepare for another invasion, the conquest of the Khiva Khanate. Military detachments led by an experienced general under the general command of von Kaufmann attacked the Khiva khanate in the spring of 1873. Despite the fact that the Khorezm patriots bravely defended every town and village 
and fiercely resisted the invaders, the Russian army won with the help of modern weapons. On May 29, 1873, Russian troops captured Khiva, the capital of the khanate, and looted the treasury of Muhammad Rahimkhan. On August 12, K.P. According to the armistice agreement between von Kaufmann and Muhammad Rahimkhan, all the lands belonging to the khanate on the right bank of the Lower Amudarya were given to Russia. The khan was deprived of the right to communicate independently with foreign countries and was forced to recognize himself as an "obedient servant of the Emperor". The Khiva khanate was preserved, but became a vassal of Russia. After the conquest of Khiva, manuscripts and archival documents, along with the material wealth of the khan's palace, were confiscated by the invaders [9.p.95]. The orientalist A.L.Kun who accompanied the Russian troops on the Khiva expedition. Oriental manuscripts collected by the day and manuscripts from the Khiva Khan's palace were brought to Tashkent and arranged. After that, A.L. Kun presented Kaufman with a report on the manuscripts and documents he had obtained during the Khiva invasion. About the number, composition and content of manuscripts taken from the Khiva khan's palace A.L.Kun the day reported the following in its report. "During the Khiva expedition the following scientific materials were collected: about 300 books of oriental manuscripts during the confiscation of the khan's palace, oriental manuscripts, including: historical works - 140 volumes in 129 titles, works of oriental poets -20 by 30 authors volume, legal-religious -40 works, 50 volumes, in addition, 18 Qur'an and 50 textbooks were collected "[10.p.96].

All these unique works were sent by Kaufman on March 28, 1874 to St. Petersburg, to the Asian Museum of the Academy of Sciences. A letter of thanks from the President of the Academy of Sciences to the Governor-General of Turkestan on April 25, 1874 confirms this. The letter read: "Your Excellency, Konstantin Petrovich. During your Khiva expedition, which you sent with your letter of March 28 this year, Mr. A.L.Kun Oriental manuscripts and books collected by the day were received by the Imperial Academy of Sciences. He instructed me to express his deep gratitude to you, Your Excellency, the Academy for sending a very important collection to the Asian Museum and trying to enrich its funds "[11.p.96]. This document testifies to the fact that the rare, priceless ancient manuscripts of Sayyid Muhammad Rahimkhan's palace were forcibly taken to St. Petersburg, the capital of the Russian Empire, at the initiative of the Governor-General of Turkestan.

Soon there was another opportunity for Russian invaders to plunder the cultural monuments of the Uzbek people, unique manuscripts and documents. This opportunity was associated with the abolition of the Kokand Khanate and the annexation of its lands to the Governor-General of Turkestan. The popular uprising that arose in 1873 under the leadership of Polatkhan lasted until February 1876. The rebels fought first against Khudoyorkhan, and after he fled, against the invaders of Tsarist Russia. They heroically defended the cities of Andizhan, Margilan, and Kokand, fought fierce battles, and inflicted heavy losses on the invaders, but were eventually defeated. The Kokand khanate, the national statehood was abolished, and colonial oppression intensified. The commanders of the armies of Tsarist Russia plundered the material and cultural wealth of the occupied cities.

As the cities of the Kokand Khanate began to be occupied by the invaders, Kaufman sent a telegram to the Chief of Staff of the Kokand Khanate of the Turkestan Military District instructing them to collect Oriental manuscripts from the occupied cities of the Khanate. He, in turn, sent a telegram to the head of the Fergana region, asking him to collect ancient manuscripts from Kokand, Margilan, Andizhan and other places [12.p.97].

On August 14, 1875, the invading forces led by K.P. Kaufman captured the city of Kokand, which was defended by the rebels led by Abdurahman Oftobachi. The capital of the Kokand Khanate was plundered by the invaders. Many valuable manuscripts were kept in the famous madrasahs and mosques of the capital, built by the khans and their high officials. Among other treasures, the invaders took the most important manuscripts and the archives of the Kokand khans as booty to Tashkent and then to St. Petersburg.

Among the more than a hundred manuscripts sent to St. Petersburg were "Tavorihi Shohruhiya", "Tarihi Muqimkhan", "Jahonnoma", "Rashakhot" and many other unique manuscripts. According to the Turkestan Military District's military headquarters, Kazbekov, a translator in Andizhan, bought many manuscripts from locals. Upon learning of this, the commander of the Turkestan military district wrote a letter to the head of the Fergana region on February 19, 1876, asking him to take the manuscripts from him and send them to Tashkent for acquaintance. He wrote: "These days it has become clear that your gentleman, your translator in Andizhan, Kazbekov, has a lot of oriental manuscripts. Various documents and manuscripts found in the former khanate may be needed in the organization of the province, in the preparation of regulations. With this in mind, I ask you to compile and send a list of personal books of the translator Kazbekov. When there is no need for them, they are sent back to him" [13.p.98].

After talking to the translator Kazbekov on behalf of the head of the Fergana region and receiving information about the manuscripts from 
him, the head of the Andizhan-Namangan army sent the following reply: "I return this order to the head of the Namangan department. He actually bought oriental manuscripts at various times from the locals and junior leaders of Andijan. But these are mostly religious books. These include the Qur'an, published in Turkey and India, the famous Persian poet Firdausi's Shahnameh, Tarikh-i Nigoristan, the manuscripts Ravzat us-Safa, Volume VI, and Tazkirat al-Awliyya, which describe the lives of Muslim saints. As for Oriental manuscripts, Kazbekov does not have them. February 22, 1876, the city of Andizhan"[14.p.99].

This document shows that in order to enrich or organize private manuscript collections, some Russian officers and officials were also engaged in the purchase and collection of manuscripts in the country. They obtained such manuscripts mainly after plundering the wealth of the cities and villages after their conquest, and in some cases bought them cheaply from the local population, which the Russian military organizations did not forbid. For example, the Russian official, orientalist A.L. Kun did not return the ancient foundations of several madrassas and mosques for scientific use. He kept some of the manuscripts demanded from the palaces of the khans and beys of Bukhara, Khiva and Kokand in his personal collection. A. The list of manuscripts in the Day collection was published in 1890 after his death. His personal archive and collection of manuscripts are now kept in the Institute of Oriental Studies of the Russian Academy of Sciences in the fund No. 33.

In the collection of Oriental manuscripts and documents, orientalists V.V. Bartold, V.V. Velyaminov-Zernov, V.I. Veselovskiy, A.L. Kun, V.V. Radlov, V.R. Rosen all were actively involved and conducted research on important manuscripts. It should be noted that Russian scholars made a great contribution to science by translating, publishing and publishing these unique manuscripts, but at the same time they served the interests of Tsarist Russia, supported its colonial policy and helped plunder Turkestan's cultural heritage.

Along with manuscripts, manuscripts, archives of Khiva and Kokand khans were taken from the territory of modern Uzbekistan to Russia. When the Khiva khanate was conquered, A.L. Kun took part in the invading armies, brought the khan's archives and manuscripts to Tashkent and studied its structure and content. Then, in December 1873, he wrote a report to the Governor-General of Turkestan on the manuscripts and documents seized in Khiva. In this document, A. Kun described the following information about the archives of Khiva khans. "When the khan's palace was confiscated, documents were collected along with manuscripts. These documents can be divided into two groups: the first group can include books on the income and expenditure of the khanate and a number of foundations and property documents, and the second group can include letters, applications, as well as diplomatic correspondence". Among the books are records on monetary taxes, books of zakat, and reports on the expenditures of the khan by Matmurad devonbegi. These documents include petitions to the khan from Khiva residents living in Bukhara, Ghazali, Istanbul, and elsewhere for trade, letters to settle land disputes, petitions for a career, and so on. Diplomatic documents include a letter from the Governor-General of East India, Nasrbruck, letters and decrees from the Sultan of Turkey, an agreement between the Russian ambassador, General Danilevsky and the Khan of Khiva, and several letters from the GovernorGeneral of Turkestan to the khan [15.p.100].

Archival documents found in the palace of the Khiva khan and confiscated by Russian invaders cover the period from 1830 to 1873 . Some of the notebooks in this archive have a serial number, some do not. This indicates that the notebooks in the archives, the documents were not numbered, there was no list of them. It is natural to question whether the existing archive is fully preserved and whether there are documents from the period before 1830 .

A.L. Kun, an orientalist who collected, studied, and arranged the archives of the Khiva khans from the palace, answered this question as follows: that the documents are incomplete - that many documents have been lost and taken away by unknown persons; b) it is unfortunate that these documents consist only of interesting material about later times "[12.p.101]. So, the archive, it was also incomplete at the time it was captured by the day. The A.L. Kun says nothing about the reasons for the disappearance of some of the documents, and we can only speculate about it. We believe that when Russian troops began to attack Khiva, the khan's officials must have taken some of the documents. In addition, after the conquest of Khiva, the khan's palace was first entered by soldiers and officers, and the palace was looted. It is possible that some documents and notebooks were taken during the looting.

It is clear that the occupation of the Khiva khanate by Russia, the looting of the khan's palace caused great damage to the archives. Due to the Russian invasion, the archives of the Khiva khans were looted, and many documents were lost.

The archives of the Khiva khans, which have not been fully preserved, were discovered by A.L. In the process of studying and arranging the day, he took the most valuable notebooks covering the socio-economic life of the khanate into his personal collection and handed over the rest to the office of the Governor-General of Turkestan. Before sending these documents to St. Petersburg, notebooks and other documents were bound and 
placed in beautiful folders. In early 1874 , the Governor-General of Turkestan sent the archives of the Khiva khans to the Imperial People's Library in St. Petersburg. The library report states: "The Honorary Member of the Library is Adjutant General K.P. Kaufman donated a collection of documents and correspondence of the Central Asian khans, which were collected during the Iskanderkul, Shakhrisabz and Khiva expeditions"[12.102]. Thus, the main part of the archives of the Khiva khans was taken to St. Petersburg and handed over to the People's Library.

After the transfer of the archives of the Khiva khans to the St. Petersburg library, the documents in the Arabic alphabet were not organized, recorded and studied in a timely manner due to the difficulty of reading them and the lack of orientalists. Historians have been unaware of the existence of these sources because no reference has been made to the archive, and for more than 60 years this unique archive has not been known to the scientific community. Finally, in 1936, the orientalist P.P.Ivanov accidentally managed to find this archive.

The library staff later forgot that these manuscripts were the archives of the Khiva khans, and did not know what these documents were because the directory was not compiled. P.P. Ivanov's study of the unknown manuscripts to determine what documents they were and to determine that they were the archives of the Khiva khans was a major event in history, as there were very few documents on the history of the Uzbek khanates before this archive was discovered and used the data of tourists. An expert on Oriental sources, scientist V.V. Barthold said: “... To date, only one category of documents, the so-called foundations, has been the research material, so only the foundations in the Samarkand region and only the historical and geographical materials in these foundations have been examined and studied" [14. p.103]. Apparently, the archives of the Khiva khans were unknown to orientalists and historians and their documents were not used. Therefore, the introduction of these archival documents into the scientific circulation is of great importance in covering the history of Central Asia, the socioeconomic life of its peoples. P.P. Ivanov did not limit himself to finding the archives of the Khiva khans, but began to study and analyze these valuable documents, despite the difficulty of putting them into scientific circulation, reading and understanding. He put the existing documents into a certain scientific system and created a commentary on the archival fund. In his work "Archive of Khiva khans of the XIX century" P.Ivanov briefly described each notebook, published important passages from these notebooks, and thus conveyed to the reader the main content of the documents in the archive.
However, P.P. Ivanov found only a part of the surviving documents, which were given to the public library, and did not know about the second part of the archive, which was kept at the Institute of Oriental Studies. From 1951 to 1956 he worked as a senior researcher at the Institute of Oriental Studies of the USSR Academy of Sciences, in 1953 he defended his doctoral dissertation on "Feudal land ownership and state structure in the Khiva Khanate". It was found by Yuldashev and put into scientific circulation. The archive of the Khiva khans was kept in St. Petersburg until 1962. At the initiative of archivists of Uzbekistan, at the request of the Government of the Republic, the State Public Library named after Saltikov-Shchedrin in Leningrad returned the archives of Khiva khans to the National Archive of Uzbekistan. However, the most valuable notebooks from the archives of the Khiva khans at the Institute of Oriental Studies of the FA in Leningrad were not given to Uzbekistan. The preservation of an entire archive in two places poses certain difficulties for historians in studying the history of the Khiva khanate.

After the Russian conquest of Kokand, the khan's palace was looted and all valuable treasures, including the archives of the Kokand khans, fell into the hands of the invaders, and like the archives of the Khiva khans, the governor-general of Turkestan, sent by Kaufman to the Imperial People's Library in St. Petersburg in 1876. The documents in the archive cover the $40 \mathrm{~s}$ and 70 s of the XIX century, the main part of which dates back to the third enthronement of Khudoyorkhan (1866-1875), a total of 5,026 pages of documents and 151 notebooks. The periodic coverage of archival documents shows that most of the archives were stolen and lost. Very few documents have survived. This was done twice by the khan's palace, in 1875 when the rebels won and Khudoyorkhan fled from Kokand to Tashkent, and in 1876 General K.P. Kaufman can be explained by the fact that Russian troops under were looted during the occupation of Kokand.

The archives seized by the Russian army are in a critical condition, with documents scattered, torn, and polluted, indicating that the archives were trampled underfoot by Russian troops after the khan's conquest. However, it contains some valuable documents, including the khan's petitions for tax exemptions or privileges, his congratulations on the appointment of khan's servants, and the involvement of the population in khashar. Another important type of document in the archive was the notebooks. The surviving 151 notebooks are an important source in illuminating the economic history of the khanate, as they contain records of tax collectors, reports, expenditures on the khan's palace, and other records. A large group of documents consists of bills, official orders, financial documents. Applications, letters and other documents written by some people to high-ranking 
officials - khans, officials - are also preserved in the archives.

The fate of the archives of the Kokand khans was the same as that of the archives of the Khiva khans. This archive also contains found by P.P. Ivanov together with the archives of Khiva khans. But he did not describe this archive scientifically. The first details of the archives of the Kokand khans were given in 1957 by the orientalist Troitskaya wrote and informed the scientific community about the structure and content of his documents. The catalog of the archives of the Kokand khans was compiled and published by the same author [15. p.105]. The archive of Kokand khans was returned to Uzbekistan in 1962 together with the archive of Khiva khans and is kept in the National Archive.

\section{CONCLUSION}

In conclusion, the transportation of the rich cultural heritage and monuments of the Uzbek people was included in the strategic plans of the Tsarist government in Central Asia and was an integral part of the policy of colonialism and plunder. This goal of tsarism was widely realized during the conquest of the country. Particular attention was paid to the organization of this work, which was important for the Tsarist government. The first governor-general of the Turkestan region, at the same time the commander of the Turkestan military district K.P. Kaufman was directly in charge of collecting the manuscripts and sending them to Russian centers. The post of Assistant Governor-General was introduced to collect study and send ancient manuscripts and other monuments to the capital's libraries and scientific centers. In addition, military governors of all regions were involved in this work. When the Central Asian khanates and their central cities were conquered, the commanders of the Russian military were instructed to collect not only material wealth but also cultural treasures. During the occupation of the Uzbek khanates, many manuscripts, archives of the khans of Khiva and Kokand were confiscated from the palaces of khans, beks, madrasahs and mosques and sent to Russia. After the conquest of Central Asia, oriental scholars, government officials and officers interested in artifacts collected and transported many manuscripts and documents to Russia. The services of Russian orientalists in the field of translation and research of manuscripts are commendable. However, there is no justification for some of them contributing to the Tsarist government's colonial policy in Turkestan, transporting ancient manuscripts to Russia instead of carefully preserving them in Turkestan, where they originated.

The occupation of the Central Asian khanates by Tsarist Russia deprived the Uzbek people of many manuscripts and documents. In the palaces of khans and beys, hundreds of Oriental manuscripts were confiscated from the hands of the local population and sent to Russian scientific centers. Due to the Russian invasion, the archives of Khiva and Kokand khans were severely damaged. Some of these archives were lost during the Russian occupation of Khiva and Kokand.

\section{REFERENCES}

1. Uzbek Soviet encyclopedia.-Tashkent: Science. 1975. Volume 6. 168-169 p.

2. National Archives of Uzbekistan, 1-fund, 29-list, 23-work, 7-8-p.

3. New history of Uzbekistan. The first book. Turkestan during the colonial period of Tsarist Russia / Editorial Board: (Chairman A. Azizkhodjaev) Sodiqov.H., Shamsutdinov. R., Ravshanov.P., Usmonov. Q.-Tashkent: Shark, 2000.-463 p.

4. National Archives of Uzbekistan, 1-fund, 15-list, 69-work, 66-p.

5. National Archives of Uzbekistan, 1-fund., 15-list, 69-work, 75-p.

6. Sadikova. N.S. Museum case in Uzbekistan. Tashkent: Fan, 1975.-129 p.

7. National Archives of Uzbekistan, 1-fund, 20-list, 6785-work, 7-p.

8. National Archives of Uzbekistan, 1-fund., 15-list, 6325-work, 4-p.

9. National Archives of Uzbekistan, 19-fund, 1-list, 10394-work.

10. National Archives of Uzbekistan, 1-fund, 20-list, 6785-work, p.8-9.

11. Report of the Imperial People's Library for 1876 - St. Petersburg: B.I., 1876.-217 p.

12. Bartold V.V. Storage of documents in the countries of the Muslim East // Archival courses. - Petrograd, 1920.380-381 p.

13. Ivanov P.P. Archive of Khiva khans of the XIX century - Leningrad: State Library, 1940. 289 p.

14. Troitskaya A.L. Archive of the Kokand khans of the 19th century (Preliminary review) // Eastern collection. - Leningrad, 1957. T 2. 185-209 p.

15. Troitskaya A.L. Catalog of the archive of the Kokand khans of the 9th century. -Moscow: Nauka, 1968-582 p. 